mgr inż. Marcin Dębiński

mgr in.. Krystian Kiercz.

dr inz. Stawomir Kowalski

NEWAG S.A. Nowy Sacz

dr inz. Tomasz Kądziolka

Państwowa Wyższa Szkoła

Zawodowa w Nowym Saczu

\title{
Przegląd rozwiązań konstrukcyjnych wybranych elektrycznych zespołów trakcyjnych
}

\begin{abstract}
$W$ artykule przedstawiono przeglad rozwiazań konstrukcyjnych wspótczesnych elektrycznych zespołów trakcyjnych na przykładzie wybranych jednostek, które w ostatnich latach zmodernizowano lub wyprodukowano w NEWAG S.A. Nowy Sacz
\end{abstract}

\section{Wprowadzenie}

Elektryczne zespoły trakcyjne serii EN i WE sa przeznaczone do obsługi lokalnego ruchu pasażerskiego. Wszystkie wagony w tych pojazdach są sprzęgnięte $\mathrm{w}$ sposób zapewniający trwałe połączenie $\mathrm{w}$ czasie eksploatacji, jednocześnie zapewniając przejście pomiędzy poszczególnymi wagonami. W skład elektrycznego zespołu trakcyjnego wchodzą wagony silnikowe oraz wagony doczepne, które na czas remontów i przeglądów mogą być rozłączane. Pociagi mogą poruszać się $\mathrm{w}$ trakcji wielokrotnej dzięki zastosowaniu automatycznych sprzęgów samoczynnych Scharfenberga. Kabina sterownicza niezależnie od konfiguracji członów znajduje się po obu końcach pojazdu. Jednostki serii EN i WE pokryte zostały farbami o zwiększonej trwałości i odpornymi na działanie czynników atmosferycznych oraz powłokami antygraffiti. Wygląd zewnętrzny i kolorystyka każdorazowo jest dopasowywana do potrzeb klienta jednocześnie nadając pojazdom nowoczesny i estetyczny wygląd. Dla podniesienia komfortu jazdy, elektryczne zespoły trakcyjne wyposażono w nowoczesne układy

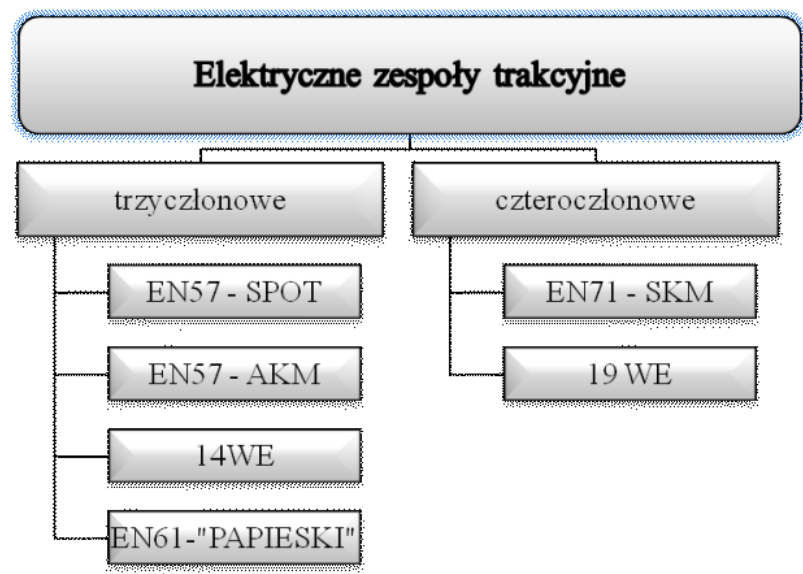

biegowe. $\mathrm{Na}$ rysunku 1 przedstawiono podział elektrycznych zespołów trakcyjnych na trzyczłonowe i czteroczłonowe, które wyprodukowano lub zmodernizowano $w$ ostatnich latach $w$ NEWAG S.A. Nowy Sącz. Natomiast podstawowe dane techniczne tych zespołów przedstawiono w tabeli 1.

\section{Opis pojazdów}

\section{- Zespół trakcyjny typu 14 WE - SKM}

Elektryczny zespół trakcyjny 14WE (rys. 2.) jest najbardziej zaawansowaną modernizacją jednostek typu EN57. Z pierwotnej konstrukcji pozostała jedynie ostoja i elementy ramy, które dla potrzeb modernizacji zregenerowano. Pojazdowi nadano nowoczesny i aerodynamiczny wygląd.

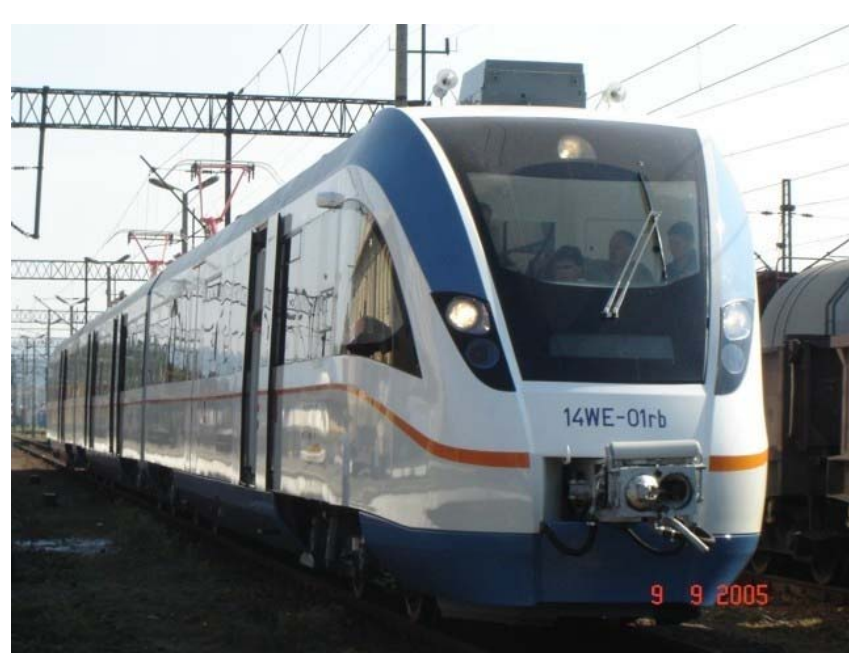

Rys. 2 Widok 14WE-SKMWA

Układ wagonów w jednostce jest oparty na systemie 410B-309B-410B (Wagon sterowniczy - wagon silnikowy - wagon sterowniczy). Podczas modernizacji zmniejszono liczbę miejsc siedzących na rzecz 


\begin{tabular}{|c|c|c|c|c|c|}
\hline Dane & $\begin{array}{c}14 W E \\
\text { SKMWA }\end{array}$ & $\begin{array}{c}\text { EN61 } \\
\text { Papieski }\end{array}$ & $\begin{array}{l}\text { EN57 } \\
\text { AKM }\end{array}$ & $\begin{array}{c}\text { EN71 } \\
\text { SKMT }\end{array}$ & $\begin{array}{c}\text { 19WE } \\
\text { SKMWA }\end{array}$ \\
\hline Rok produkcji & 2005 & $2005 / 2006$ & $2008 / 2009$ & 2009 & $2009 / 2010$ \\
\hline $\begin{array}{l}\text { Długość (ze sprzę- } \\
\text { gami) }\end{array}$ & $68400 \mathrm{~mm}$ & $68400 \mathrm{~mm}$ & $64770 \mathrm{~mm}$ & $86840 \mathrm{~mm}$ & $86500 \mathrm{~mm}$ \\
\hline $\begin{array}{l}\text { Masa pojazdu } \\
\text { próżnego }\end{array}$ & $125 \mathrm{t}$ & $125 \mathrm{t}$ & $126 t \pm 3 \%$ & $170 \mathrm{t}$ & $190 \mathrm{t} \pm 3 \%$ \\
\hline $\begin{array}{l}\text { Maksymalna masa } \\
\text { brutto pojazdu }\end{array}$ & $165 \mathrm{t}$ & $165 \mathrm{t}$ & $165 \mathrm{t}$ & $182 \mathrm{t}$ & $260 \mathrm{t}$ \\
\hline $\begin{array}{l}\text { Liczba drzwi wej- } \\
\text { ściowych }\end{array}$ & 12 & 12 & 12 & 16 & 20 \\
\hline $\begin{array}{l}\text { Szzerokość przej- } \\
\text { ścia w części pasa- } \\
\text { żerskiej }\end{array}$ & $820 \mathrm{~mm}$ & $820 \mathrm{~mm}$ & $820 \mathrm{~mm}$ & $820 \mathrm{~mm}$ & $800 \mathrm{~mm}$ \\
\hline $\begin{array}{l}\text { Wysokość podłogi } \\
\text { od główki szyny }\end{array}$ & $1157 \mathrm{~mm}$ & $1157 \mathrm{~mm}$ & $1157 \mathrm{~mm}$ & $1157 \mathrm{~mm}$ & $1150 \mathrm{~mm}$ \\
\hline Układ miejsc & $2+2$ & $\begin{array}{c}\text { Autobus i } \\
2+2\end{array}$ & $2+2$ & $\begin{array}{l}\text { Metro i } \\
2+2\end{array}$ & $\begin{array}{c}\text { Metro i } \\
2+2\end{array}$ \\
\hline $\begin{array}{l}\text { Liczba miejsc } \\
\text { siedzące/stojące }\end{array}$ & $184 / 225$ & $181 / 283$ & $190 / 210$ & $234 / 288$ & $182 / 374$ \\
\hline $\begin{array}{l}\text { Liczba miejsc dla } \\
\text { osób niepełno- } \\
\text { spraw. }\end{array}$ & 2 miejsca & 8 miejsc & 2 miejsca & 2 miejsca & 2 miejsca \\
\hline $\begin{array}{l}\text { Winda dla niepel- } \\
\text { nospraw. }\end{array}$ & TAK & TAK & TAK & brak & TAK \\
\hline $\begin{array}{l}\text { Maksymalna pręd- } \\
\text { kość eksploatacyj- } \\
\text { na }\end{array}$ & $110 \mathrm{~km} / \mathrm{h}$ & $110 \mathrm{~km} / \mathrm{h}$ & $120 \mathrm{~km} / \mathrm{h}$ & $120 \mathrm{~km} / \mathrm{h}$ & $160 \mathrm{~km} / \mathrm{h}$ \\
\hline $\begin{array}{l}\text { Laczna moc ciagła } \\
\text { silników trakcyj- } \\
\text { nych }\end{array}$ & $608 \mathrm{~kW}$ & $740 \mathrm{~kW}$ & $1000 \mathrm{~kW}$ & $2000 \mathrm{~kW}$ & $2240 \mathrm{~kW}$ \\
\hline $\begin{array}{l}\text { Przyśpieszenie } \\
\text { rozruchu około: }\end{array}$ & $0,5 \mathrm{~m} / \mathrm{s}^{2}$ & $0,5 \mathrm{~m} / \mathrm{s}^{2}$ & $0,8 \mathrm{~m} / \mathrm{s}^{2}$ & $0,8 \mathrm{~m} / \mathrm{s}^{2}$ & ok. $1 \mathrm{~m} / \mathrm{s}^{2}$ \\
\hline toczny & 36AN & $36 \mathrm{AN}$ & 36AN & 36AN & 70RSTa \\
\hline napędny & $23 \mathrm{MN}$ & $23 \mathrm{MN}$ & $23 \mathrm{MN}$ & $23 \mathrm{MN}$ & 70RSNa \\
\hline Układ osi & $\begin{array}{l}2^{\prime} 2^{\prime}+\mathrm{Bo}^{\prime} \mathrm{Bo}{ }^{\prime} \\
+2^{\prime} 2^{\prime}\end{array}$ & $\begin{array}{l}2^{\prime} 2^{\prime}+\mathrm{Bo}^{\prime} \mathrm{Bo}{ }^{\prime} \\
+2^{\prime} 2^{\prime}\end{array}$ & $\begin{array}{l}2^{\prime} 2^{\prime}+\text { Bo'Bo' } \\
+2{ }^{\prime}{ }^{\prime}\end{array}$ & $\begin{array}{l}\text { 2'2'+ Bo'Bo'+ } \\
\text { Bo'Bo' }+ \\
2^{\prime} 2^{\prime}\end{array}$ & $\begin{array}{l}\text { Во'Bo'+ } \\
2^{\prime} 2^{\prime}+\text { Bo'Bo' }\end{array}$ \\
\hline
\end{tabular}

miejsc stojących, co jest bardziej praktyczne w przewozach aglomeracyjnych. Fotele dwumiejscowe zamontowano w układzie rzędowym lub naprzeciwległym (rys. 3). Wnętrze pojazdu w pełni przystosowano do przewozów osób niepełnosprawnych na wózkach inwalidzkich. Wydzielono również miejsce dla osób z większym bagażem i rowerzystów. W pojeździe zamontowano podnośniki umożliwiające wsiadanie osobom niepełnosprawnym do jednostki.

W celu zwiększenia bezpieczeństwa podróżnych w zespole trakcyjnym dotychczas stosowane lusterka zewnętrzne umożliwiające obserwację otoczenia zewnętrznego pojazdu zastapiono zestawem kamer zewnętrznych zamontowanych na zewnątrz pojazdu.
W każdym wagonie rozrządczym, na zewnatrz po obydwu stronach kabiny maszynisty zamontowane i okablowane zostały dwie kamery zewnętrzne, hermetyczne. Kamery te współpracują z monitorem 14" umieszczonym na pulpicie.

W kabinie maszynisty dokonano modernizacji pulpitu (rys. 3) dostosowując go do obecnie istniejących standardów ergonomii i wyposażenia.

Pojazd wyposażono w zmodernizowane wózki $23 \mathrm{MN}$ z silnikami LKF450 o mocy $185 \mathrm{~kW}$ i wózki 36AN. 

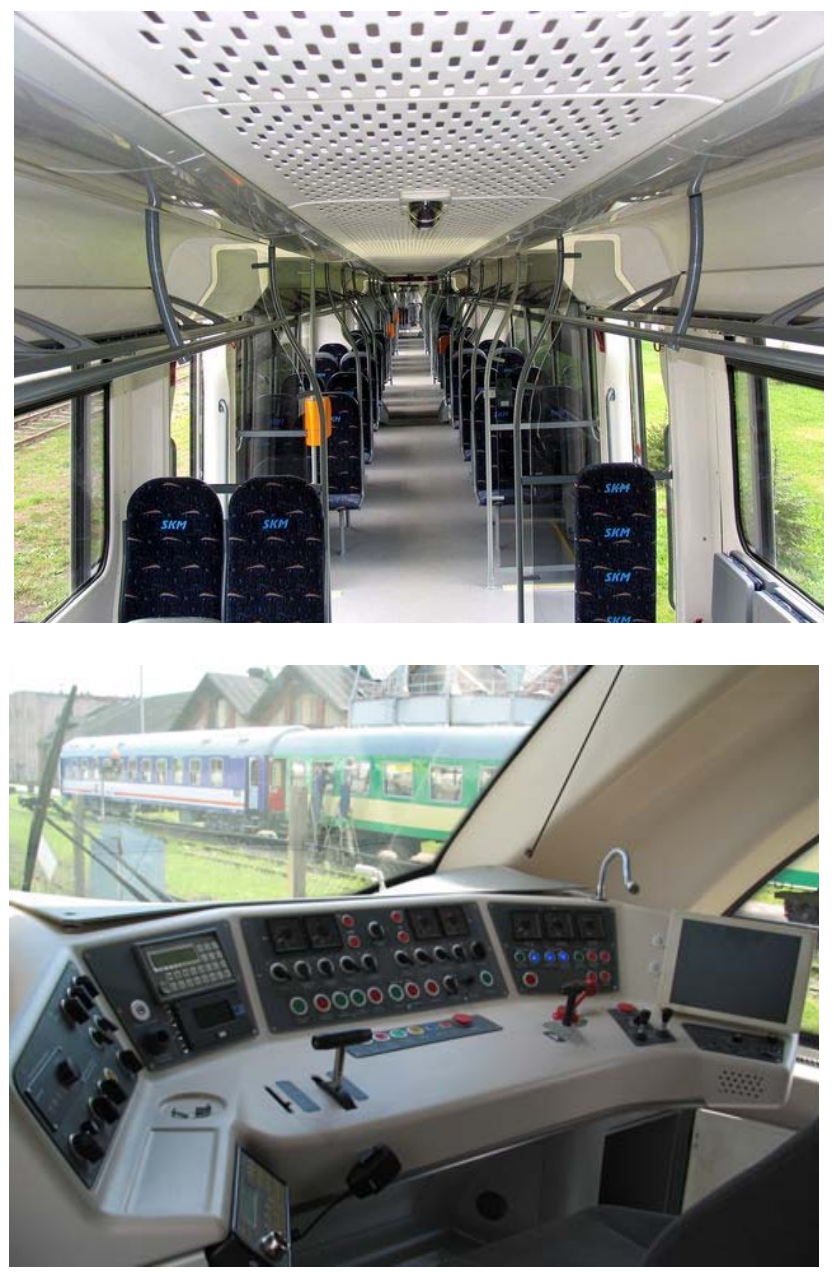

Rys. 3 Wnętrze 14WE - SKMWA

\section{- Zespól trakcyjny typu EN61 - „Papieski”}

Elektryczny zespół trakcyjny EN61 - „Papieski” (rys. 4) został zaprojektowany przez krakowską firmę EC Engineering i wykonany przez nowosądecką firmę Newag jako podziękowanie polskich kolejarzy za pontyfikat Jana Pawła II. W dniu 28 maja 2006 roku pociagg poświęcił podczas wizyty w Polsce Papież Benedykt XIV.

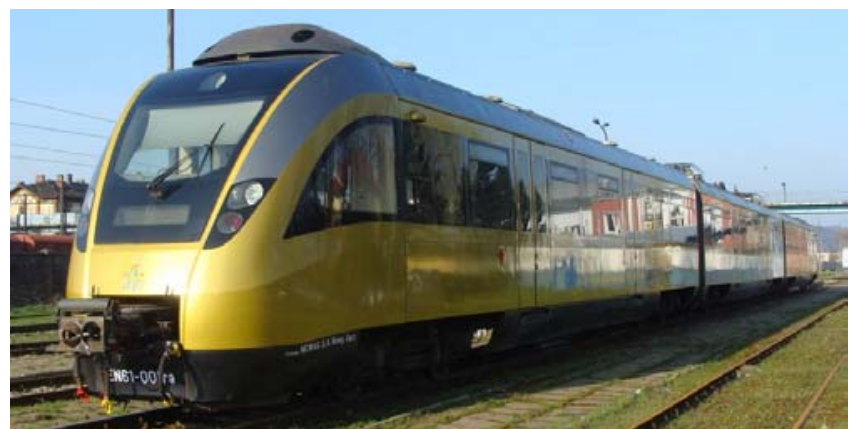

Rys. 4 Widok EN61 Pociag Papieski"

Pociąg papieski został zbudowany na podstawie elektrycznego zespołu trakcyjnego 14WE. Różnica pomiędzy pojazdami występuje jedynie w kolorystyce i wyposażeniu przedziału pasażerskiego. Wnętrze pojazdu zaopatrzono $\mathrm{w}$ jedną toaletę $\mathrm{w}$ członie rozrządczym A. Toaleta jest wyposażona w system zam- knięty firmy SEMCO, który współpracuje ze zbiornikami umieszczonymi za jej tylną ścianą. Konstrukcja oraz wyposażenie umożliwia korzystanie $\mathrm{z}$ toalety osobom niepełnosprawnym.

Kanapy, siedzenia odchylne, fotele dwumiejscowe (rys. 5) usytuowane w układzie rzędowym lub naprzeciwległym $(2+2)$ są wykonane $\mathrm{z}$ materiału zapewniającego odpowiedni komfort i trwałość.
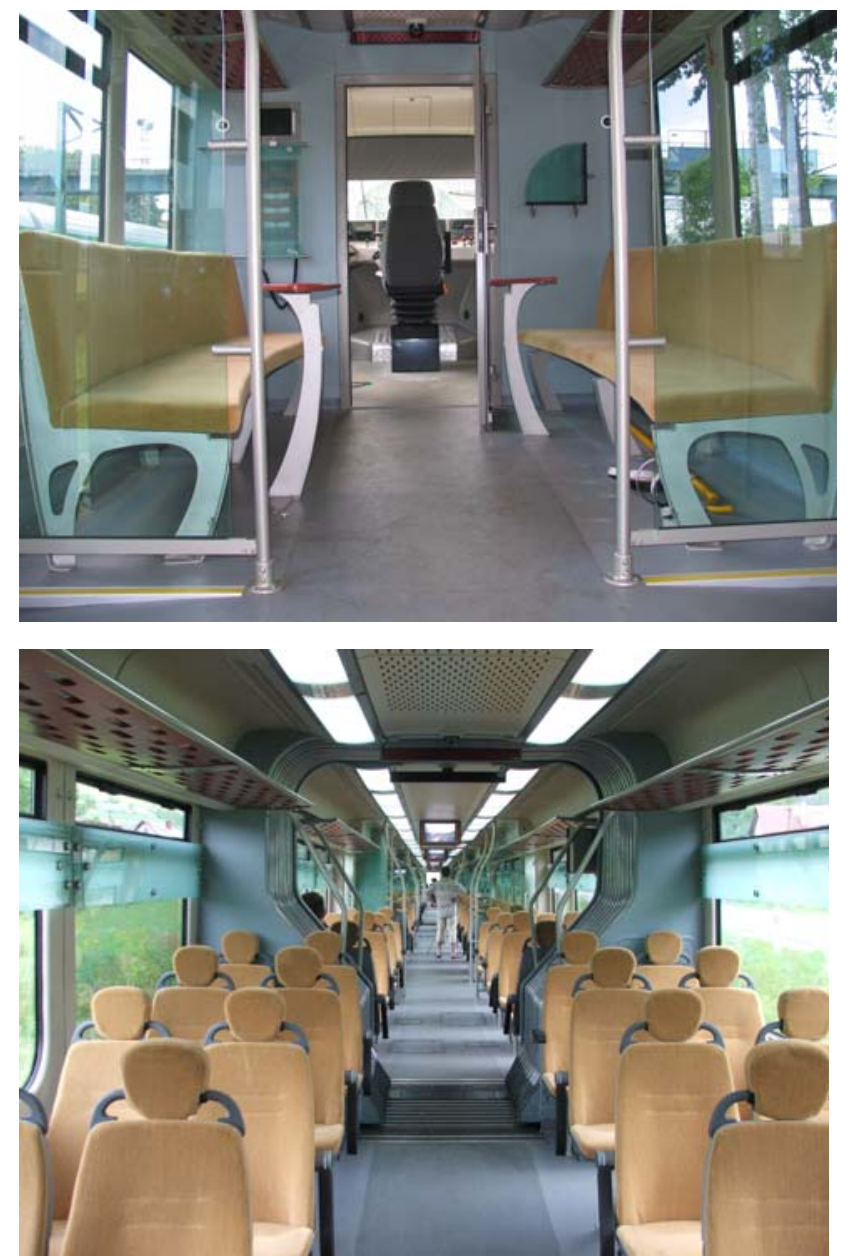

Rys. 5 Wnętrze EN61 „Pociąg Papieski”

W członie rozrządczym $\mathrm{C}$ wydzielono przedział „studio", w którym zamontowano urządzenia do obsługi systemu multimedialnego. Przedział "studio" wyposażono m.in. w monitory 17 " LCD, odtwarzacze DVD, wielokanałowy system audio $\mathrm{z}$ indywidualnymi panelami odsłuchowymi dla każdego pasażera pozwalający na odsłuch prezentacji multimedialnych w różnych językach, kamery kolorowe obserwujące obraz z czoła pociagu. W przedziale tym można oglądać emitowane materiały filmowe i zdjęcia dotyczące życia Jana Pawła II.

Kolorystyka zewnętrzna pojazdu została wykonana w barwach papieskich, tj. w kolorach: złotym i białym, oraz wykonano napis TOTUS TUUS.

W elektrycznym zespole trakcyjnym EN61 jak i w 14WE zmodernizowano układ cięgłowo-zderzny. W pojazdach zastosowano sprzegi czołowe typu Scharfenberga, które umożliwiają automatyczne połączenie 
dwóch pojazdów bez dodatkowej obsługi.

Pociag papieski wyposażono $\mathrm{w}$ taki sam układ jezdny jak EZT 14WE.

\section{- Zespoły trakcyjne typu: EN57 - AKM i EN - 71 SKM}

Przy okazji napraw głównych elektrycznych zespołów trakcyjnych EN-57 i EN-71 dokonano modernizacji niektórych elementów pojazdów. Zakres modernizacji obejmował m.in.: zastapienie przetwornicy wirującej przetwornicą statyczną, zabudowę nowego wyłącznika szybkiego, montaż stojaków na rowery, zastosowanie silników asynchronicznych do napędu, zabudowę systemu monitoringu, modernizację czoła (rys. 6) i kabiny maszynisty.

Konstrukcja kabiny maszynisty została zmieniona poprzez wykonanie nowego szkieletu stalowego wkomponowanego w pozostałą część jednostki. Na szkielet, stosując klejenie, nałożono samonośne czoło $\mathrm{z}$ laminatu poliestrowo - szklanego. W czole wklejono szybę panoramiczną.

$\mathrm{W}$ modernizowanych pojazdach zrezygnowano $\mathrm{z}$ drzwi zewnętrznych do przedziałów dla podróżnych z większym bagażem ręcznym, natomiast zabudowano nowe drzwi zewnętrzne bezpośrednio do kabin maszynisty. Powierzchnię zewnętrzną jednostek, oraz drzwi wejściowe pomalowano $\mathrm{w}$ ustalonej z użytkownikami kolorystyce farbami poliuretanowymi chemoutwardzalnymi, oraz farbami proszkowymi.

a)

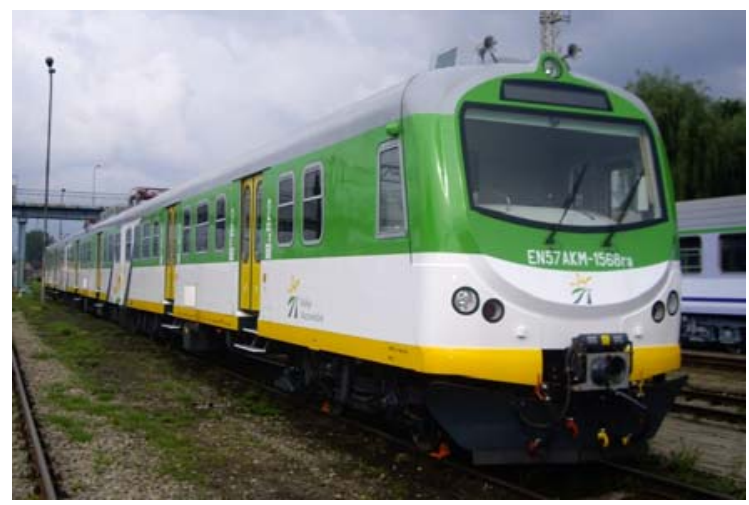

b)

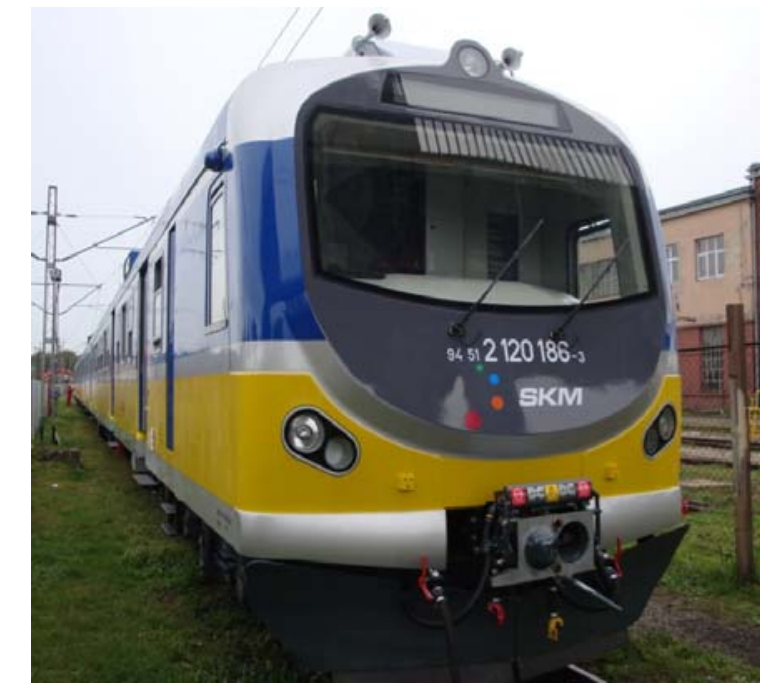

Rys 6 Widok a) EN57 - AKM, b) EN71 - SKM
W modernizowanych elektrycznych zespołach trakcyjnych zlikwidowano ściany i drzwi przedziałowe. W to miejsce zamontowano ,wiatrochrony” wykonane w dolnej części z blach nierdzewnych, w górnej część ze szkła bezpiecznego a na ściance wiatrochronu zamontowano uchwyty dla stojących pasażerów.

a)

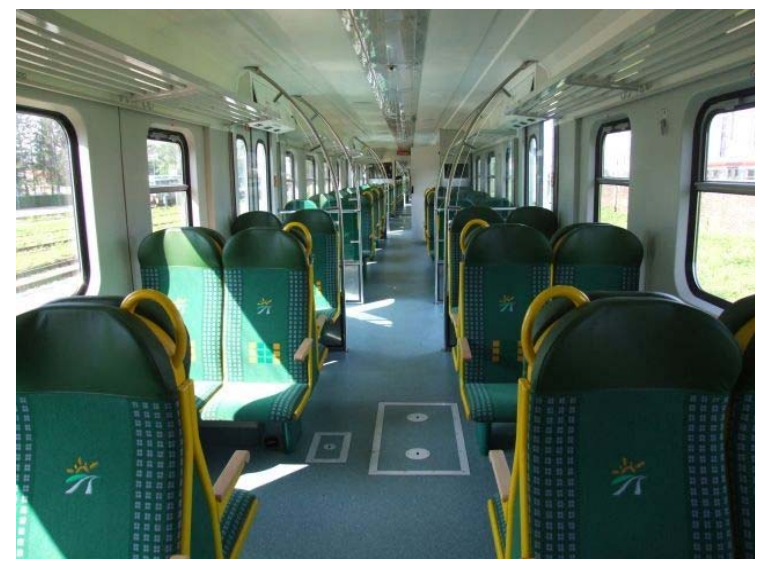

Rys. 7 Wnętrze pojazdów a) EN57 AKM, b) EN 71 SKM

b)

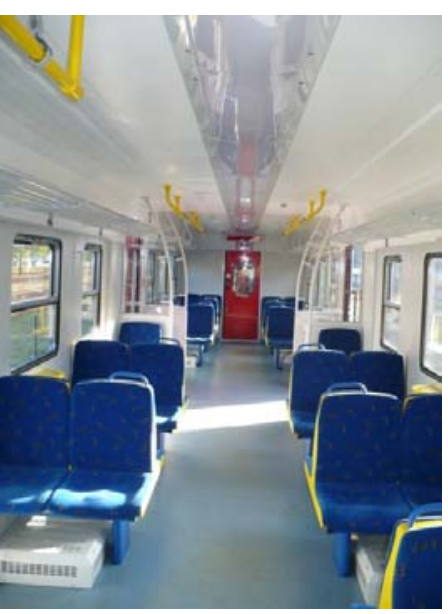

Pozostałe wyłożenie wnętrza (rys. 7), jak ściany boczne i sufit wykonano z paneli z niepalnych żywic poliestrowo szklanych. Niezbędne listwy wykończeniowe wykonano $\mathrm{z}$ tworzyw sztucznych niepalnych lub profili stalowych. Izolację termiczną i dźwiękochłonną wagonów stanowi w ścianach bocznych i suficie mata $\mathrm{z}$ wełny mineralnej o grubości $50 \mathrm{i}$ $30 \mathrm{~mm}$ pokryta jednostronnie folią aluminiowa, a w podłodze wagonów płyty styropianowe o grubości 30 $\mathrm{mm}$. Całość podłogi wyłożono w systemie wannowym wykładziną podłogową o grubości $3 \mathrm{~mm}$ trudnościeralną, ułatwiając czyszczenie i mycie wagonu.

W pojazdach przewidziano przedziały służbowe, które dostosowano do przewozu osób na wózkach inwalidzkich. Przedziały te zostały dodatkowo wyposażone w specjalne stojaki do przewożenia rowerów w pozycji pionowej. Ponadto $\mathrm{w}$ wagonie rozrządczym EZT EN71-SKM wydzielono przedział drugiej klasy z siedzeniami w układzie „metro”.

Napęd elektrycznych zespołów trakcyjnych jest realizowany przez asynchroniczne silniki trakcyjne 2xANT-500-3000-UF. Napęd ten składa się z dwóch 
falowników napięcia ANT500-3000, silników napędowych M1, M2, M3, M4 z czujnikami prędkości oraz temperatury, układu łagodnego włączenia falowników oraz dławików sieciowych EN57, zabudowanych w rozdzielni wysokiego napięcia RWN EN57. Obwód wysokiego napięcia składa się ponadto $\mathrm{z}$ dwóch pantografów, jednego odłącznika trakcyjnego, jednego wyłącznika szybkiego i zespołu uziemiaczy.

W EZT EN57 - KM zamontowano system pomiaru potoków pasażerskich, który jest przeznaczony do rejestrowania strumienia pasażerów korzystających $\mathrm{z}$ pojazdów. Zapewnia on rejestrację stopnia zapełnienia i liczby pasażerów w rozbiciu na wsiadających i wysiadających - w korelacji z poszczególnymi przystankami i kursami. Zebrane przez niego dane umożliwiają prowadzenie obliczeń i zaawansowanych analiz statystycznych, które ułatwiają optymalizację funkcjonowania całej sieci komunikacyjnej oraz poszczególnych kursów i linii. Część pomiarowa podsystemu składa się z sensorów (aktywnych czujników ruchu w podczerwieni) typu IRS-320, modułów wejść cyfrowych typu INP-450 oraz koncentratorów TSL998/IBIS.

Na czole EZT-ów oraz w wnękach bocznych zainstalowanych po bokach wagonu silnikowego zostały zabudowane tablice świetlne serii ETLP12420007 informujące o kierunku jazdy. Ponadto wykonano instalację rozgłoszeniową przeznaczoną do nadawania i odtwarzania komunikatów.

W celu zwiększenia bezpieczeństwa podróżnym podczas jazdy, w elektrycznych jednostkach trakcyjnych zainstalowano system monitoringu, który jest przeznaczony do obserwacji i rejestracji zdarzeń we wszystkich wagonach. Realizowany jest przez ukryte kamery. Obraz z kamer wyświetla się na 2 monitorach 17' LCD umieszczonych po jednym $\mathrm{w}$ każdej $\mathrm{z}$ dwóch kabin maszynisty.

EN57 - AKM i EN71 - SKM wyposażono w zmodernizowane wózki napędne $23 \mathrm{MN}$ z silnikiem asynchronicznym LK 450X6 o mocy znamionowej 250 $\mathrm{kW}$ i sprawności przekraczającej $94 \%$ oraz wózki toczne 36AN.

Ze względu na trakcję wielokrotną wykonano modernizację sprzęgów czołowych typu ZEa, w firmie Dellner Couplers, zgodnie z dokumentacją modernizacji sprzęgów zatwierdzoną przez Urząd Transportu Kolejowego. Sprzęgi te umożliwiają automatyczne połączenie dwóch pojazdów bez dodatkowej obsługi. Rozłączanie jest realizowane przyciskiem z kabiny maszynisty lub manualnie. Sprzęg pozwala na pochłonięcie energii zderzenia oraz absorbuje szarpnięcia pomiędzy pojazdami.

Połączenie dwóch członów jest zrealizowane przez dotychczas stosowane sprzęgi stałe ZEk. Ze względu na konstrukcję i budowę pojazdu, do przeprowadzenia połączeń elektrycznych pomiędzy poszczególnymi członami, zastosowano wiązki kablowe zakończone wtykami oraz gniazdami hermetycznymi Hartinga.

\section{- Zespól trakcyjny typu 19WE - SKM}

Elektryczny zespół trakcyjny 19WE w odróżnieniu od wcześniej opisanych konstrukcji jest pojazdem całkowicie nowym zarówno pod względem konstrukcyjnym jak i wykonania. Podstawowym układem wagonów jest układ $\mathrm{s}^{\prime}+\mathrm{d}+\mathrm{d}+\mathrm{s}^{\prime}$ (wagon silnikowy + wagon doczepny + wagon doczepny + wagon silnikowy). $\mathrm{Na}$ rysunku 8 pokazano ogólny widok elektrycznego zespołu trakcyjnego 19WE.

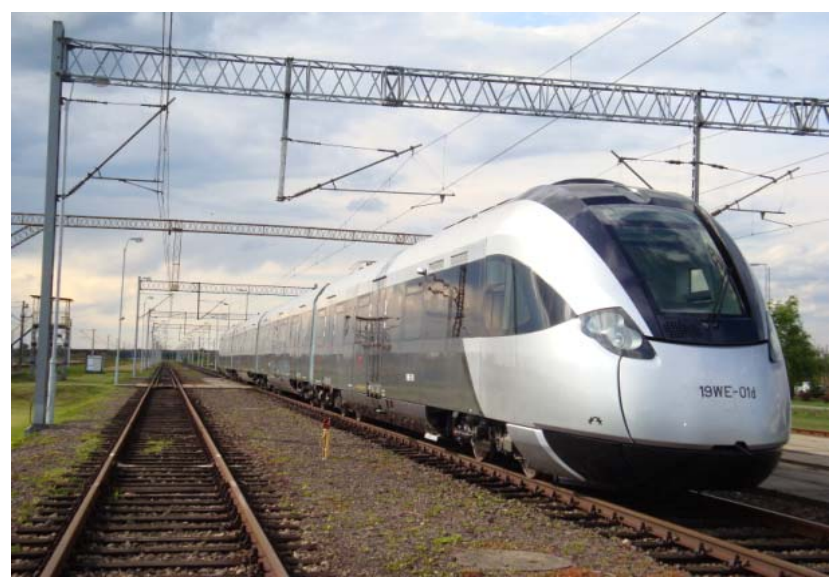

Rys. 8. Widok zewnętrzny EZT 19WE

Konstrukcja pudła EZT 19WE jest konstrukcja spawaną, składaną z elementów łączonych systemem interlock. Wszystkie elementy użyte do budowy pojazdu spełniają wymogi norm w zakresie bezpieczeństwa przeciwpożarowego oraz nie zawierają azbestu. Konstrukcja pudła jest konstrukcją samonośną przenoszącą obciążenia bez trwałych odkształceń, wykonaną ze stali niskostopowych o podwyższonych parametrach wytrzymałościowych i podwyższonej odporności na korozję. Pudło pojazdu zabezpieczono antykorozyjnie, dźwiękochłonnie i w sposób thumiący drgania. Ściany wyłożono izolacją typu moniflex, natomiast podłogę wełną mineralną.

W pojeździe zastosowano nowy zespół drzwi bocznych odskokowo-przesuwnych firmy Ultimate o prześwicie $1300 \mathrm{~mm}$ ze stałymi oknami. Drzwi posiadają napęd główny ruchu drzwi odskok + przesunięcie realizowany przy zastosowaniu silników elektrycznych krokowych. Po wejściu pasażera drzwi zamykaja się automatycznie po czasie 3 sekund. Jeżeli w przestrzeni drzwiowej w momencie zamykania pojawi się pasażer, jego obecność sygnalizowana jest do układu sterowania przez zespół fotokomórek umieszczonych w obrębie drzwi co powoduje ponowne ich otwarcie. Wszystkie drzwi pojazdu są automatycznie zamykane w ruchu pojazdu po przekroczeniu przez pojazd prędkości $5 \mathrm{~km} / \mathrm{h}$. Podczas ruchu pojazdu drzwi są blokowane i nie ma możliwości ich otwarcia lub wysterowania. 
Kabinę maszynisty (rys. 9) wykonano w taki sposób, żeby spełniała wymagania bezpieczeństwa pracy i ergonomii określone $\mathrm{w}$ normie PN-90/K11001. Natężenie oświetlenia w kabinie maszynisty posiada regulację w zakresie 0-150 lx.
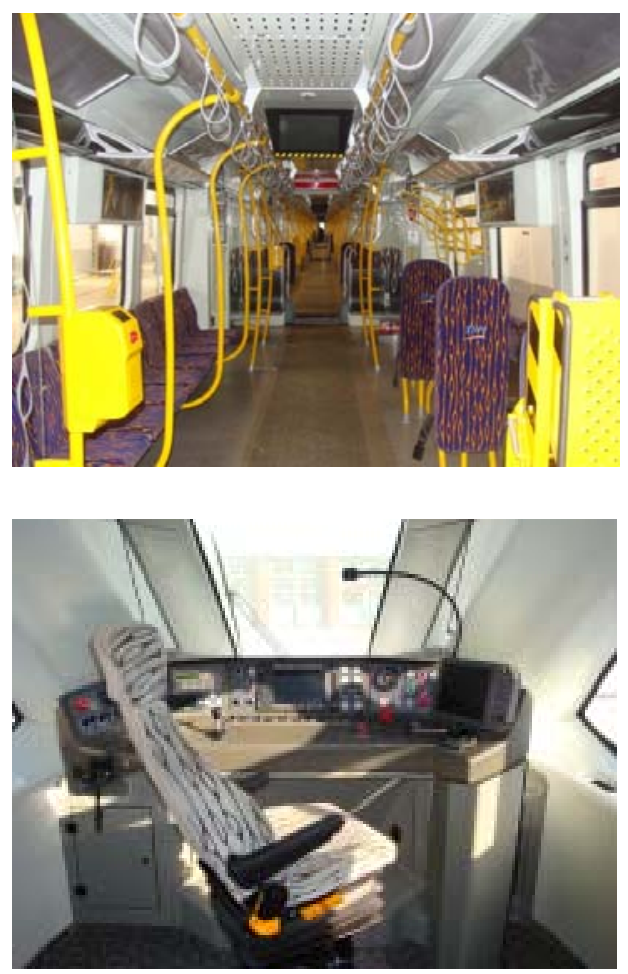

Rys. 9 Wnętrze 19WE - SKMWA

W celu uzyskania jak największej przestrzeni pasażerskiej $\mathrm{w}$ pojeździe zamontowano fotele $\mathrm{w}$ układzie „metro" (rys. 9). Ponadto w wagonie pierwszym i ostatnim oprócz układu foteli „metro" zamontowano po dwa rzędy foteli w układzie rzędowym, naprzeciwległym.

W wagonie silnikowym, wydzielono dwa miejsca dla osób niepełnosprawnych korzystających z wózków inwalidzkich. W miejscach tych zamontowano fotele odchylne jednoosobowe i zaczepy mocujące wózek inwalidzki. Ponadto w wagonie tym zamontowano dwa podnośniki dla niepełnosprawnych.

Wnętrze elektrycznego zespołu trakcyjnego 19WE jest w pełni klimatyzowane. Funkcja wentylacji i schładzania powietrza jest realizowana przez niezależne układy, po jednym na każdy z członów pojazdu. Agregaty wentylacyjne zlokalizowano w centralnej części dachu każdego z członów. Nominalna wydajność chłodnicza pojedynczej centrali wynosi $\mathrm{Q}_{\mathrm{CHVAC}}=35 \mathrm{~kW}$, nominalny przepływ powietrza cyrkulacyjnego wynosi $\mathrm{V}_{\mathrm{NHVAC}}=3800 \mathrm{~m}^{3} / \mathrm{h}$.

Pojazd posiada system informacji audio-wizualnej. W tym celu zastosowano tablice informacyjne nowej generacji typu ETLZ-U. Wszystkie informacje wyświetlane na tablicach są dosyłane szyną transmisji RS485.
W skład systemu informacji głosowej wchodzą: urządzenie głośnomówiące GRG-4500M1, wzmacniacz linii WL-100, transformatory głośnikowe i mikrofon. Dodatkowo zamontowano ekrany LCD, na których mogą być wyświetlane różne ogłoszenia a nawet reklamy.

Elektryczne zespoły trakcyjne wyposażono w system rejestracji drogi, prędkości i parametrów pojazdu. Jego zadaniem jest zbieranie i rejestracja informacji o stanie i pracy pojazdu oraz jego podzespołów oraz wyświetlanie maszyniście podstawowych parametrów jazdy na wyświetlaczu ATM-PW3.

Ze względu na trakcję wielokrotną zastosowano sprzęgi czołowe firmy Voith. Sprzęgi te umożliwiaja automatyczne połączenie dwóch pojazdów bez dodatkowej obsługi. Rozłączanie jest realizowane przyciskiem z kabiny maszynisty lub manualnie. Sprzęg pozwala na pochłonięcie energii zderzenia oraz absorbuje szarpnięcia pomiędzy pojazdami. Połączenie dwóch członów jest zrealizowane przez sprzęg półstały produkcji firmy Voith. Połówki tego sprzęgu są połączone sprzęgłem łubkowym.

Jednostki wyposażono w wózki napędne typu 70RSNa z silnikami asynchronicznymi typu ANT3003000 o mocy znamionowej $300 \mathrm{~kW}$, oraz w wózki toczne typu 70RSTa. Szczegółową budowę tych wózków przedstawiono $\mathrm{w}$ rozdziale 3 .

\section{Opis wózków}

\section{- Wózki typu: 23MN i 36AN}

Wózki typu 5B i 6B zastosowane w elektrycznych zespołach trakcyjnych EN57 i EN71, w trakcie naprawy uległy modernizacji zgodnie $\mathrm{z}$ dokumentacją konstrukcyjną nr RL - 4780 i RL - 4781 wykonaną przez Instytut Pojazdów Szynowych w Poznaniu. Modernizacja ta polega na zmianie sposobu usprężynowania zestawów kołowych z podwójnego na usprężynowanie $\mathrm{z}$ zastosowaniem sprężyn gumowometalowych stożkowych (rys. 10).

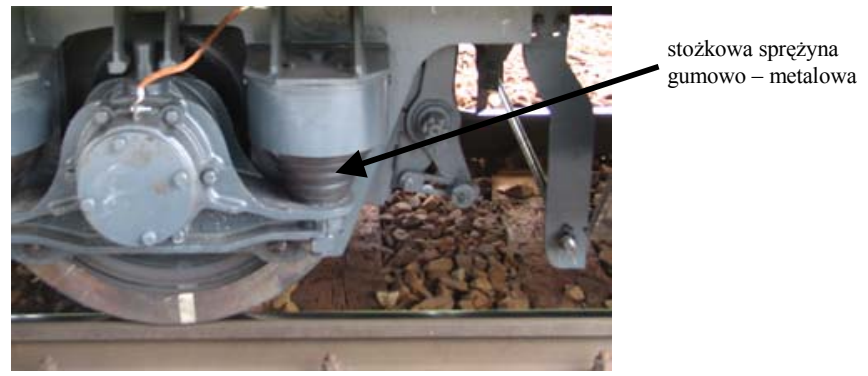

Rys. 10. Usprężynowanie I-go stopnia elektrycznego zespołu trakcyjnego EN57

Automatycznie zmianie uległo prowadzenie zestawów kołowych poprzez zastosowanie nowego typu oprawy łożysk specjalnie wykonanej dla ww. modernizacji. Modernizacja ta znacznie poprawia 
spokojność biegu pojazdu, a zatem i komfort podróżowania. Ponadto dla tłumienia drgań poprzecznych i pionowych, wózki są zaopatrzone w amortyzatory hydrauliczne pionowe i poziome. Zarówno wózki napędne $\mathrm{i}$ toczne posiadają nowy typ oprawy dla łożysk NJ + NJP 130 × 240 × 80 mm, uwzględniający zmiany usprężynowania I stopnia.

\section{- Wózki typu: 70RSNa i 70RSTa}

Wózki 70RSNa i 70RSTa (rys.11) zamontowano w elektrycznych zespołach trakcyjnych 19WE. Rama wózka, stanowiąca przestrzenną konstrukcję spawaną, składa się z dwóch ostojnic, połączonych kształtową poprzecznicą tak, aby uzyskać w miejscu połączenia jak najmniejszy teoretyczny współczynnik koncentracji naprężeń.

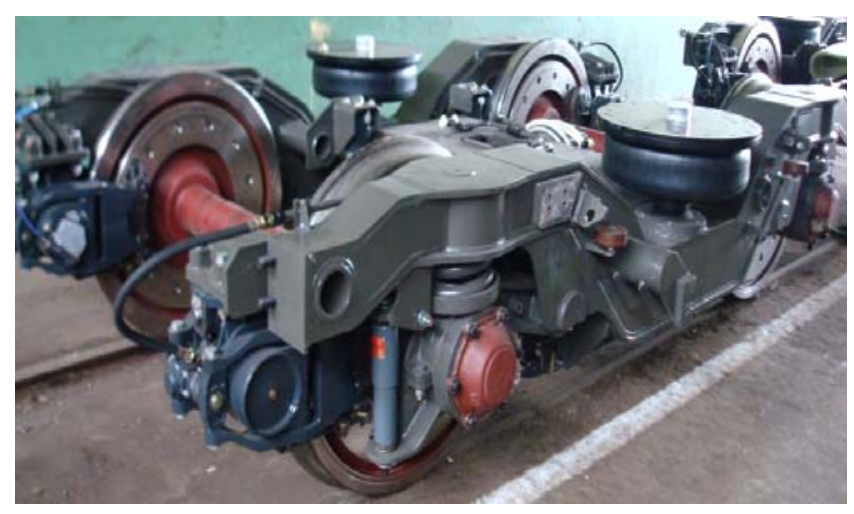

Rys.10. Wózek 70RSTa
Zestaw kołowy jest prowadzony w ramie wózka za pomoca jednostronnego wahacza połączonego $\mathrm{z}$ ramą przegubem gumowo-metalowym, składającym się ze sworznia amortyzującego i pierścieni amortyzujących. Usprężynowanie I-go stopnia składa się z czterech kompletów współśrodkowych podwójnych sprężyn śrubowych. Sprężyny każdego kompletu spoczywają na wahaczach w prowadzeniach i są naciskane ramą wózka przez podkładkę gumową i prowadzenie. Jako usprężynowanie II-go stopnia zastosowano w wózku dwie sprężyny pneumatyczne firmy PHOENIX typu SEK 680-12.

\section{Zakończenie}

Przedstawione w niniejszym artykule przykłady rozwiązań konstrukcyjnych elektrycznych zespołów trakcyjnych pokazują, że użytkownicy taboru szynowego chętniej poddają modernizacji posiadany tabor niż kupują nowy. Fakt ten jest uzasadniony, gdyż koszt modernizacji równy jest ok. 50\% wartości kupna nowego pojazdu. Decyzja o modernizacji taboru wynika także ze względu na krótszy czas i mniejszy koszt przeprowadzania badań potrzebnych do dopuszczenia do eksploatacji. Ponadto zmodernizowane pojazdy spełniają wszelkie wymagania techniczne stawiane nowobudowanym pojazdom szynowym, co można zauważyć porównując zmodernizowane elektryczne zespoły trakcyjne EN57 i EN71 z nowobudowanym pojazdem 19WE.

\section{Literatura}

[1] „DTR EZT EN71 z napędem asynchronicznym”, Nowy Sacz 2009.

[2] „DTR EZT EN57 z napędem asynchronicznym”, Nowy Sqcz 2009.

[3] „DTR EZT typu 19WE”, Nowy Sacz 2009. 